\title{
¿FFECTS OF HUMAN GROWTH HORMONE ON LEVELS OF BLOOD AND URINARY CARBOHYDRATE AND FAT METABOLITES IN MAN *
}

\author{
By DOROTHY H. HENNEMAN $\dagger$ AND PHILIP H. HENNEMAN $\dagger$ \\ (From the Division of Anesthesia, Department of Surgery, Peter Bent Brigham Hospital; \\ Department of Medicine, Massachusetts General Hospital; and the Harvard \\ Medical School, Boston, Mass.)
}

(Submitted for publication November 2, 1959; accepted April 14, 1960)

In an accompanying paper (1) human growth hormone $(\mathrm{HGH})$ was reported to have stimulated the rate of linear growth, produced retention of nitrogen, phosphorus, magnesium, calcium, sodium and potassium, and perhaps increased the rate of fat mobilization in ten human subjects. This paper describes the response of blood and urinary levels of fat and carbohydrate intermediary metabolites in seven of these and in one infant with hyperinsulinism. ${ }^{1}$

Some effects of $\mathrm{HGH}$ on carbohydrate and fat metabolism have already been published. Raben and Hollenberg (2) observed a prompt and significant rise in plasma free fatty acids (FFA). Beck, McGarry, Dyrenfurth and Venning (3) reported alterations in glucose tolerance in four of six patients and Ikkos, Luft and Gemzell (4) in two of two patients. Ikkos and associates also observed elevations in ketone bodies in three of four patients. The data to be reported in general confirm these observations and include the simultaneous measurements of blood and urinary glucose, lactate, pyruvate, citrate, $\alpha$-ketoglutarate, free fatty acids and ketones during short and longterm HGH therapy.

\section{MATERIAL AND METHODS}

The clinical features of the patients studied are reported elsewhere (1). The subjects include 5 patients

* Presented in part at The Endocrine Society, San Francisco, June, 1958. Supported in part by a grant from the Research and Development Division, Office of Surgeon General, U. S. Army Contract DA-49-507-MD798.

$\dagger$ Present address: Seton Hall College of Medicine, Jersey City, N. J.

1 Studied through the courtesy of Dr. John Crigler, Children's Medical Center, Boston, Mass. A second partial pancreatectomy completely alleviated the patient's hypoglycemia. with hypopituitarism, 1 patient with obesity on an 800 calorie diet and 1 patient with proven hyperinsulinism (5). All patients were studied under constant conditions.

Blood levels of carbohydrate and fat intermediary metabolites were measured 4,8 and 24 hours after injections of 1.0 to $10.0 \mathrm{mg}$ of acid-soluble $\mathrm{HGH}$ (Raben). ${ }^{2} \mathrm{HGH}$ was administered as a single intramuscular injection at 6 a.m. (or beginning of "metabolic day") daily for 2 to 36 days.

The methods for measurement of blood and urinary glucose, lactic, pyruvic, $\alpha$-ketoglutaric and citric acids, acetone and total ketones, and inorganic phosphorus have been reported previously (6). In addition, plasma FFA were measured by the method of Davis (7) as modified by Gordon and Cherkes (8). Balance studies were conducted according to the method of Reifenstein, Albright and Wells (9).

\section{RESULTS}

HGH (1) produced a decrease in blood urea nitrogen (BUN) and urinary nitrogen in 24 to 48 hours which was not apparent within the first four hours after injection. With constant daily $\mathrm{HGH}$ injections, nitrogen retention increased for 3 to 5 days, was maximal for 2 weeks, and then decreased to low levels in the fourth and fifth weeks of treatment. If $\mathrm{HGH}$ were discontinued for 12 days and then resumed, nitrogen retention was again marked. Other constituents of protoplasm were retained in the relative concentrations characteristic of most tissues.

Because of the multiphasic nature of the nitrogen response to $\mathrm{HGH}$ the measurements of intermediary metabolites have been separated as follows: the early phase ( 4 hours to 3 days), as nitrogen retention is developing; the second phase ( 3 to 15 days) during sustained maximal nitrogen

2 Similar responses were obtained with a procainehydrochloride precipitate of $\mathrm{HGH}$ (Raben) (1). This preparation of procaine was epinephrine-free. 
TABLE I

Early effects of $H G H$ on levels of plasma FFA, serum citrate and blood glucose*

\begin{tabular}{|c|c|c|c|c|c|c|c|c|c|c|c|c|c|c|}
\hline \multirow[b]{2}{*}{ Patient } & \multicolumn{2}{|c|}{$\begin{array}{c}\text { HGH } \\
\text { treatment }\end{array}$} & \multicolumn{4}{|c|}{$\begin{array}{l}\text { FFA, plasma } \\
\text { Hours after HGH }\end{array}$} & \multicolumn{4}{|c|}{$\begin{array}{l}\text { Citrate, serum } \\
\text { Hours after } \mathrm{HGH}\end{array}$} & \multicolumn{4}{|c|}{$\begin{array}{l}\text { Glucose, blood } \\
\text { IIours after HGH }\end{array}$} \\
\hline & & Day & 0 & 4 & 24 & 48 & 0 & 4 & 24 & 48 & 0 & 4 & 24 & 48 \\
\hline M.C. & $\begin{array}{c}m g / d a y \\
2.5\end{array}$ & $\begin{array}{l}0 \\
1 \\
4\end{array}$ & $\begin{array}{l}0.30 \\
0.15\end{array}$ & $m E$ & $\begin{array}{l}L \\
0.32 \\
0.32\end{array}$ & & $\begin{array}{l}1.75 \\
2.08\end{array}$ & $m g / 1$ & $\begin{array}{l}0 \mathrm{ml} \\
2.50 \\
2.41\end{array}$ & & 74 & $m g / 1$ & 64 & \\
\hline J.C. & $\begin{array}{l}5.0 \\
5.0 \\
5.0\end{array}$ & $\begin{array}{l}1 \\
2 \\
1\end{array}$ & $\begin{array}{l}0.63 \\
0.71\end{array}$ & $\begin{array}{l}1.31 \\
1.85 \\
1.20\end{array}$ & $\begin{array}{l}1.08 \\
0.70\end{array}$ & $\begin{array}{l}0.53 \\
0.71\end{array}$ & $\begin{array}{l}3.58 \\
1.92 \dagger\end{array}$ & $\begin{array}{l}3.0 \\
3.83 \\
4.70\end{array}$ & $\begin{array}{l}4.50 \\
2.7\end{array}$ & $\begin{array}{l}1.0 \\
1.25\end{array}$ & $\begin{array}{r}124 \\
78\end{array}$ & $\begin{array}{r}100 \\
100 \\
50\end{array}$ & $\begin{array}{r}101 \\
75\end{array}$ & $\begin{array}{l}72 \\
74\end{array}$ \\
\hline L.C. & 5.0 & $\begin{array}{l}0 \\
1 \\
2\end{array}$ & $\begin{array}{l}0.80 \\
0.95\end{array}$ & $\begin{array}{l}1.05 \\
1.45\end{array}$ & 0.94 & $\begin{array}{l}0.78 \\
0.82 \ddagger\end{array}$ & 3.65 & $\begin{array}{l}3.70 \\
3.83\end{array}$ & 3.2 & $\begin{array}{l}2.50 \\
2.53 \ddagger\end{array}$ & 83 & $\begin{array}{r}84 \\
115\end{array}$ & 78 & $\begin{array}{l}86 \\
88 \ddagger\end{array}$ \\
\hline B.D. & $\begin{array}{l}2.5 \\
5.0 \\
5.0 \\
5.0\end{array}$ & $\begin{array}{l}1 \\
1 \\
1 \\
2\end{array}$ & $\begin{array}{l}0.74 \\
0.67\end{array}$ & 0.91 & $\begin{array}{l}0.69 \\
0.95 \\
0.65\end{array}$ & 0.69 & $\begin{array}{l}3.60 \\
2.82\end{array}$ & 3.86 & $\begin{array}{l}4.5 \\
5.0 \\
4.4 \\
4.5\end{array}$ & $\begin{array}{l}3.42 \\
3.4\end{array}$ & 74 & 74 & $\begin{array}{l}47 \\
81 \\
95\end{array}$ & $\begin{array}{l}73 \\
79\end{array}$ \\
\hline
\end{tabular}

* All blood samples (from antecubital vein) were obtained after a 12 to 15 hour fast; HGH was administered 4 hours before the blood sample. M.C., J.C. and L.C. were hypopituitary patients, and B.D. was an obese subject on an 800 calorie diet. Blood levels of pyruvate, lactate, ketones and $\alpha$-ketoglutarate were not significantly altered during this early phase.

$\dagger$ This value may reflect a depression subsequent to the administration of cortisone two days before (10).

$\ddagger$ Value 72 hours after last dose of $\mathrm{HGH}$.

retention; and the third phase (15 to 36 days), as nitrogen retention declines to low levels.

\section{The early phase (4 hours to 3 days)}

1. Plasma FFA. Fasting concentrations of FFA were increased 4 hours after each of several injections of $\mathrm{HGH}$ in two patients with hypopituitarism and in the obese patient (Table I). Levels were elevated 8 to 12 hours after $\mathrm{HGH}$ in the infant with hyperinsulinism (Table II). Levels were not elevated 24 hours after the first dose of $\mathrm{HGH}$, but were elevated 24 hours following the second dose of $\mathrm{HGH}$ in one of three subjects (Table I).

2. Serum citric acid. Fasting concentrations of serum citric acid were definitely increased 4 to 8 hours after $\mathrm{HGH}$ in three of five observations (J. C., second course; B.D. following $5.0 \mathrm{mg}$ $\mathrm{HGH}$; and P.H; see Tables I and II). Levels were elevated 24 hours after $\mathrm{HGH}$ in four of five subjects. Concentrations fell below control in all patients upon discontinuing $\mathrm{HGH}$ (Tables I and II) during this phase.

3. Twenty-four hour urinary citrate, acetone and total ketones. Control urinary excretion of citric acid in the five patients with hypopituitarism was $283 \mathrm{mg}$ per 24 hours, a level which is significantly less $(p<0.001)$ than normal (mean of normal subjects on constant diet was $480 \mathrm{mg}$; SE $28 \mathrm{mg}$ ). Daily urinary acetone and ketone levels were within normal limits during the con-

TABLE II

Effects of HGH on plasma FFA, serum citrate and blood glucose in an infant with hyperinsulinism*

\begin{tabular}{lccccc}
\hline HGH treatment & $\begin{array}{c}\text { Day of } \\
\text { treat- } \\
\text { ment }\end{array}$ & $\begin{array}{c}\text { Hours } \\
\text { after last } \\
\text { dose }\end{array}$ & FFA & Citrate & $\begin{array}{c}\text { Glu- } \\
\text { cose }\end{array}$ \\
\hline & & & $m E q / L$ & $\begin{array}{c}m g / 100 \\
m l\end{array}$ & $\begin{array}{c}m g / 100 \\
m l\end{array}$ \\
1.0 mg/12 hours & 0 & & 0.36 & 1.60 & 48 \\
for 6 days & $\begin{array}{c}\text { (Control) } \\
1\end{array}$ & 8 & 0.45 & 1.40 & \\
& 1 & 12 & 1.16 & 2.83 & 29 \\
& 6 & 12 & 1.36 & 1.83 & 24 \\
& 7 & 8 & 1.36 & 2.83 & 25 \\
2.5 mg/day & 10 & 8 & 1.36 & 2.26 & \\
for 6 days & 12 & 24 & 0.78 & 1.16 & 20 \\
& 6 & & 0.56 & & \\
Postcontrol & 12 & & 0.46 & 0.3 & 22 \\
& & & & &
\end{tabular}

* All samples were taken after a 4 to 8 hour fast. The patient was fed every 8 hours. Glucose levels were measured every 3 to 4 hours. Values listed for control represent mean of a 6 day period prior to HGH. Patient received HGH for 12 consecutive days and showed a significant increase above control in nitrogen retention during this period (5) 
trol period. Urinary excretion of citrate, acetone and ketones increased significantly $(p<0.01)$ during the first 24 hours after the injection of 1.0, 2.5 or $5.0 \mathrm{mg}$ of $\mathrm{HGH}$ in all patients studied except the patient with obesity (Table III). In the patients with hypopituitarism, mean citrate excretion rose from 283 (SE $20 \mathrm{mg}$ ) to $362 \mathrm{mg}$ (SE $17 \mathrm{mg}$ ); mean acetone from 2.1 (SE 0.5 $\mathrm{mg}$ ) to $7.5 \mathrm{mg}$ ( $\mathrm{SE} 1.7 \mathrm{mg}$ ); and mean ketones from 15 (SE $3.3 \mathrm{mg}$ ) to $32 \mathrm{mg}$ per 24 hours (SE $5.4 \mathrm{mg}$ ). In Patient S.M., urinary acetone, ketone and citrate increased further with each 1 mg injection of $\mathrm{HGH}$ administered every third day (Table III) ; the degree of rise in ketones was greater than that in citrate. In the patient with obesity (B.D., Figure 1 and Table III) urinary citrate and ketones fell during the first 24 to 72 hours of $\mathrm{HGH}$ administration.

\section{The second phase ( 3 to 15 days)}

1. Plasma FFA. Fasting levels of FFA (24 hours after each injection of $\mathrm{HGH}$ ) rose above control by the sixth day of $\mathrm{HGH}(2.5 \mathrm{mg})$ in the one patient with hypopituitarism so tested (M.C., Figure 2), were not increased on the sixth day but were on the fourteenth day of $\mathrm{HGH}(2.5 \mathrm{mg}$ per day) in the patient with obesity (B. D., Figure 1), and were elevated in the infant with hyperinsulinism on the sixth, seventh, tenth and twelfth days of HGH (Table II). Once elevated, FFA concentrations generally remained above control during the first two weeks of therapy (Figure 2, Table II).

2. Serum and urinary citric acid. During the first two weeks of daily $\mathrm{HGH}$ treatment, fasting serum and/or urinary citrate rose in five patients (B.D., Figure 1; M.C., Figure 2; P.H., Table II ; M.A., Table IV; and S.M., Table V). Serum levels were not elevated in one of the patients with hypopituitarism (M.A., Table IV) on the twelfth day of $\mathrm{HGH}$ administration at a time when nitrogen retention was still marked; however, urinary citrate excretion on this day was $260 \mathrm{mg}$ above control.

In the obese patient, B.D., the initial fall in urinary citrate during Phase I of $\mathrm{HGH}$ was followed by a gradual rise to levels above control throughout the period of maximal nitrogen retention. Increasing the dose of $\mathrm{HGH}$ from 2.5 to $5.0 \mathrm{mg}$ produced a second transient decrease in citrate excretion to a low of $379 \mathrm{mg}$ per 24 hours on the third day (Days 66 to 72, charted as two

TABLE III

Early effects of HGH on urinary metabolites*

\begin{tabular}{|c|c|c|c|c|c|c|c|c|c|c|c|c|c|}
\hline \multirow[b]{3}{*}{ Patient } & \multirow[b]{3}{*}{ Dose HGH } & \multicolumn{4}{|c|}{ Acetone } & \multicolumn{4}{|c|}{ Ketones } & \multicolumn{4}{|c|}{ Citrate } \\
\hline & & \multirow[b]{2}{*}{ Control } & \multicolumn{3}{|c|}{ Day of treatment } & \multirow[b]{2}{*}{ Control } & \multicolumn{3}{|c|}{ Day of treatment } & \multirow[b]{2}{*}{ Control } & \multicolumn{3}{|c|}{ Day of treatment } \\
\hline & & & 1 & 2 & 3 & & 1 & 2 & 3 & & 1 & 2 & 3 \\
\hline & & \multicolumn{4}{|c|}{$m g / 24$ hrs } & \multicolumn{4}{|c|}{$m g / 24 \mathrm{hrs}$} & \multicolumn{4}{|c|}{$\mathrm{mg} / 24 \mathrm{hrs}$} \\
\hline M.C. & $2.5 \mathrm{mg} /$ day & 4.0 & 3.6 & 4.1 & 3.7 & 21.6 & 24.0 & 21.2 & & 214 & 325 & 320 & 338 \\
\hline S.M. & $\begin{array}{l}1 \mathrm{mg} / 3 \text { days } \\
1 \mathrm{mg} / 3 \text { days } \\
1 \mathrm{mg} / 3 \text { days } \\
1 \mathrm{mg} / 3 \text { days }\end{array}$ & 1.7 & $\begin{array}{l}6.0 \\
4.5 \\
3.9 \\
2.3\end{array}$ & $\begin{array}{r}6.9 \\
9.2 \\
12.0\end{array}$ & $\begin{array}{r}2.0 \\
4.0 \\
3.8 \\
11.0\end{array}$ & 4.7 & $\begin{array}{l}20.8 \\
45.3 \\
12.5 \\
62.3\end{array}$ & $\begin{array}{l}20.8 \\
62.3\end{array}$ & $\begin{array}{l}18.2 \\
12.5 \\
62.3\end{array}$ & 280 & $\begin{array}{l}307 \\
330 \\
357 \\
249\end{array}$ & $\begin{array}{l}307 \\
330 \\
249 \\
340\end{array}$ & $\begin{array}{l}290 \\
297 \\
\\
340\end{array}$ \\
\hline M.A. & $2.5 \mathrm{mg} / \mathrm{day}$ & 2.1 & 11.1 & 9.1 & 10.0 & 17.5 & 37.5 & 39.8 & 21.8 & 330 & 400 & 400 & 466 \\
\hline L.C. & $5 \mathrm{mg} /$ day & & & & & 24.0 & 40.0 & 15.3 & & 325 & 486 & 295 & \\
\hline J.C. & $\begin{array}{l}\text { I } 5 \mathrm{mg} / \text { day } \\
\text { II } 5 \mathrm{mg} / \text { day }\end{array}$ & $\begin{array}{l}0.4 \\
0.9\end{array}$ & $\begin{array}{l}0.5 \\
6.0\end{array}$ & 3.9 & & $\begin{array}{l}16.8 \\
24.5\end{array}$ & 34.0 & 21.9 & & $\begin{array}{l}321 \\
245 \dagger\end{array}$ & $\begin{array}{l}370 \\
328\end{array}$ & 296 & \\
\hline B.D. & $2.5 \mathrm{mg} / \mathrm{day}$ & 12.0 & 19.4 & 17.2 & 15.8 & 58.0 & 34.3 & 65.3 & 65.3 & 555 & 535 & 320 & 320 \\
\hline
\end{tabular}

* All but B.D. were hypopituitary patients. B.D. was an obese subject on an 800 calorie diet. S.M. received single injections of $1 \mathrm{mg} \mathrm{HGH}$ every 3 days; values listed were obtained on the first, second and third days af ter each of these injections. J.C. study was as follows: fore-control (3 days); HGH $5 \mathrm{mg}$ per day (2 days); postcontrol (3 days); cortisone $10 \mathrm{mg}$ per day (2 days); postcontrol (3 days); and finally HGH $5 \mathrm{mg}$ per day (1 day). No significant changes in urinary pyruvate or lactate were observed.

$\dagger$ Values, second control, immediately followed cortisone administration which would be expected to lower urinary citrate (10). 


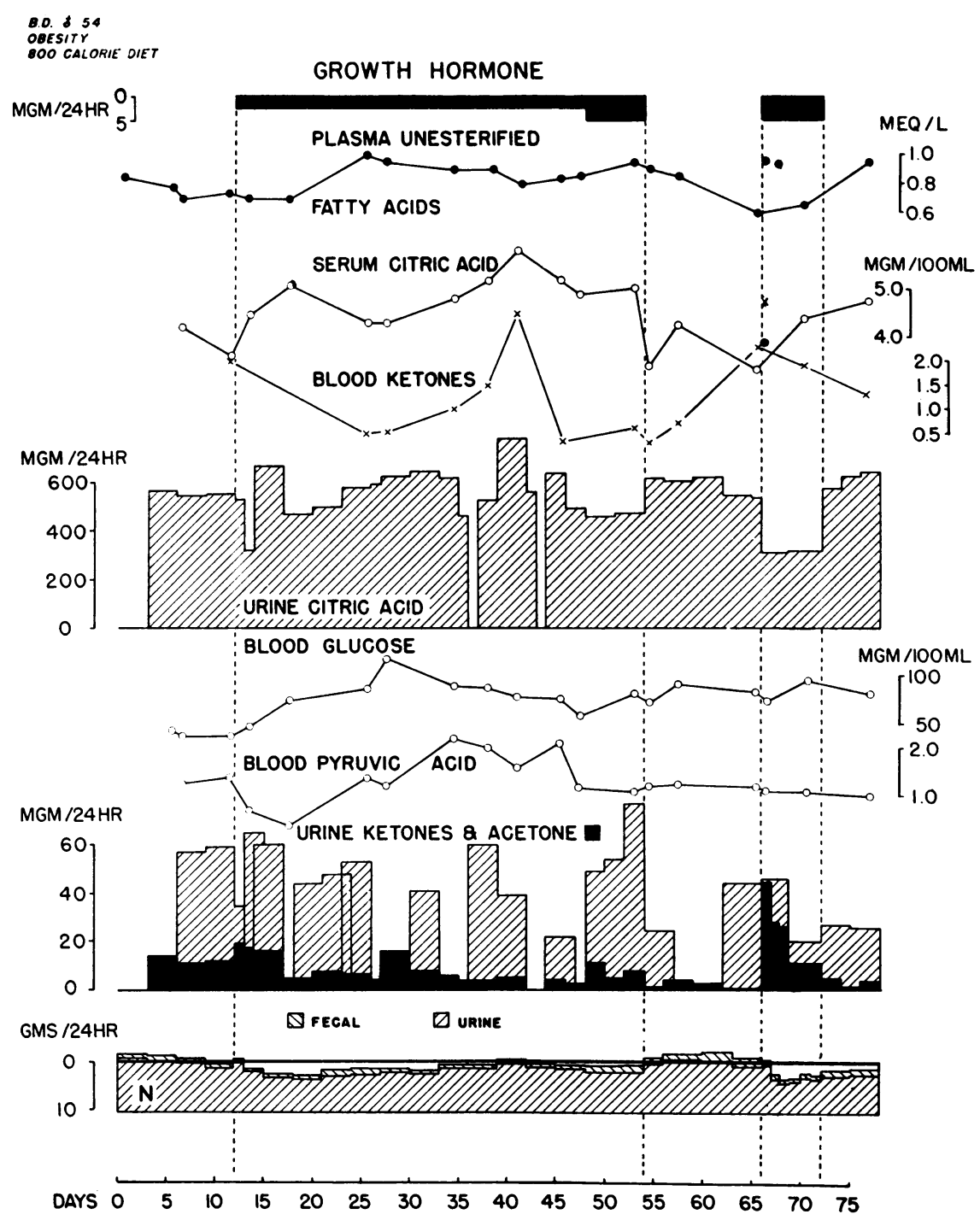

Fig. 1. EFfects of HGH dURing CAloric Restriction of an obese patient (B.D.). The patient was on an 800 calorie constant diet for 12 days prior to and during the entire study. Her initial weight was 440 pounds. All blood samples were obtained in the fasting state 24 hours after the last dose of $\mathrm{HGH}$ except on Days 66 and 67 when blood samples were obtained 4 hours after $\mathrm{HGH}$ (values plotted separately). Urinary citrate, acetone and ketones were not measured on the days where no values are charted. Overlapping of lines in urinary ketones represents measurements made on aliquots of different 3-day pools of urine. Plasma unesterified fatty acids $=$ free fatty acids (FFA).

3-day pools in Figure 1). Nitrogen retention at this time was considerably more than that observed during the first course of $5 \mathrm{mg} \mathrm{HGH}$ per day.

3. Blood $\alpha$-ketoglutaric acid. Fasting concentrations of $\alpha$-ketoglutaric acid increased from 0.12 to $0.47 \mathrm{mg}$ per $100 \mathrm{ml}$ by the sixth day of $\mathrm{HGH}$ (2.5 $\mathrm{mg}$ per day in B.D., the patient with obesity). Levels remained above control and abnormally high during the first two weeks of $\mathrm{HGH}$ in this patient.

4. Glucose metabolism. Fasting concentrations of glucose progressively decreased in Patient M.C. (Figure 2) and increased in the patient with obesity (B.D., Figure 1). There was no significant change on the twelfth day of treatment in 
TABLE IV

Effect of prolonged HGH therapy in hypopituitarism*

\begin{tabular}{|c|c|c|c|c|c|c|c|c|c|c|}
\hline \multirow[b]{3}{*}{ Treatment } & \multirow[b]{3}{*}{ Duration } & \multicolumn{5}{|c|}{ Venous blood levels } & \multicolumn{4}{|c|}{ Urinary excretion } \\
\hline & & \multirow{2}{*}{$\begin{array}{l}\text { Glu- } \\
\text { cose }\end{array}$} & \multirow{2}{*}{$\begin{array}{l}\text { Pyru- } \\
\text { vate }\end{array}$} & \multirow[b]{2}{*}{ Lactate } & \multirow[b]{2}{*}{ Citrate } & \multirow[b]{2}{*}{ Ketones } & \multicolumn{2}{|c|}{ Citrate } & \multicolumn{2}{|c|}{ Ketones } \\
\hline & & & & & & & Mean & $\mathrm{SE}$ & Mean & SE \\
\hline & days & \multicolumn{5}{|c|}{$\mathrm{mg} / 100 \mathrm{ml}$} & \multicolumn{4}{|c|}{$\mathrm{mg} / 24 \mathrm{hrs}$} \\
\hline Fore-control & 12 & 60 & 1.4 & 7.5 & 2.8 & 0.68 & 330 & 16.9 & 17.5 & 0.8 \\
\hline $\begin{array}{l}\mathrm{HGH} \\
\quad 2.5 \mathrm{mg} / \text { day }\end{array}$ & (Day $\left.{ }^{12} 3-15\right)$ & 69 & 1.7 & 8.0 & 2.5 & 0.44 & 531 & 5.4 & 19.3 & 3.3 \\
\hline $\begin{array}{l}\mathrm{HGH} \\
2.5 \mathrm{mg} / \text { day }\end{array}$ & $\begin{array}{c}15 \\
\text { (Day } 15-30)\end{array}$ & 68 & 1.6 & 6.5 & 2.13 & 0.75 & 545 & 20.0 & 21.5 & 1.0 \\
\hline
\end{tabular}

* Patient M.A.; fasting, 10 a.m. blood samples were drawn on last day of designated period, and 4 hours after daily administration of $\mathrm{HGH}$. Cortisone, $10 \mathrm{mg}$ daily, was administered throughout the study. Values for urinary levels represent mean excretion during entire designated period. Urinary levels of pyruvate and lactate showed no significant change. $\mathrm{SE}=$ standard error of the mean.

Patient M.A., but glucose tolerance was decreased at this time: 1) Control test: fasting, $60 ; 1$ hour past glucose, 68 ; and 2 hours past glucose, $54 \mathrm{mg}$ per $100 \mathrm{ml}$. 2) After 12 days of $\mathrm{HGH}$ : fasting, 69 ; 1 hour past glucose, 123 ; and 2 hours past glucose, $105 \mathrm{mg}$ per $100 \mathrm{ml}$.

5. Twenty-four hour urinary excretion of ketones. During the period of maximal nitrogen retention, urinary ketones fluctuated but were generally above control in the three patients with hypopituitarism. In M.A. and S.M. (Tables IV and V) cortisone appeared to decrease the degree of ketonuria relative to the rise in citrate. Withdrawal of cortisone in S.M. was followed by an increase in ketonuria (Table V).
Due to caloric restriction, fore-control levels of plasma FFA $(0.74 \mathrm{mEq}$ per $\mathrm{L})$, serum citrate (3.6 $\mathrm{mg}$ per $100 \mathrm{ml}$ ), urinary ketones $(60 \mathrm{mg}$ per 24 hours) and urinary citrate (555 $\mathrm{mg}$ per 24 hours) were all abnormally elevated in B.D. prior to HGH. Urinary acetone and blood and urinary ketones fell to normal levels during nitrogen retention (Figure 1 ).

\section{The third phase (15 to 36 days)}

By the end of the fourth week, daily administration of $\mathrm{HGH}$ in the hypopituitary patients resulted in waning nitrogen retention (1) and similar declines toward control in levels of plasma FFA, and serum and urinary citrate (Figures 1

TABLE $\mathrm{V}$

Effects of prolonged HGH therapy in hypopituitarism*

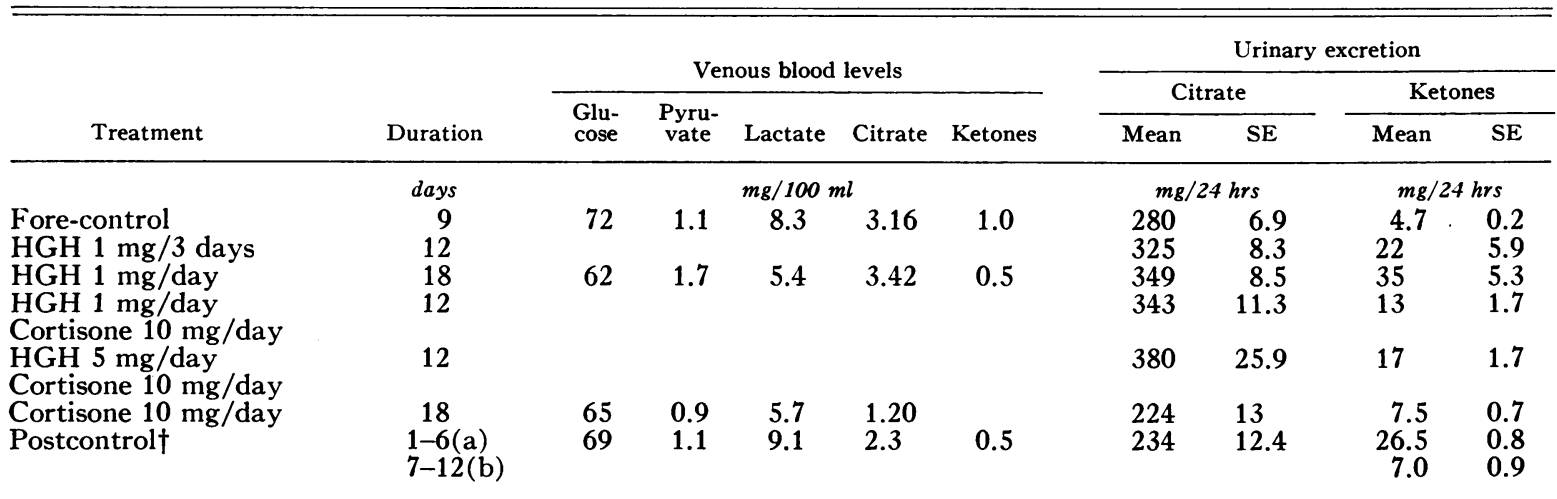

* Patient S.M. ; fasting 10 a.m. blood levels were drawn on last day of designated periods, and 4 hours after medication. Urinary excretions represent mean of all observations of entire control or treatment period. Urinary levels of lactate and pyruvate showed no significant change.

+ Postcontrol period with no treatment is divided into the first 6 days (a) and the second 6 days (b) for ketone values. No significant difference in other urinary metabolites was observed between the first and second 6 day postcontrol periods. 
and 2). In B.D., waning nitrogen retention was accompanied by a decline in plasma FFA and blood $\alpha$-ketoglutaric acid $(0.22 \mathrm{mg}$ per $100 \mathrm{ml}$ on Day 45 of study). Urinary citrate and ketones were at or below control in B.D. during the fifth week of treatment.

During the third and fourth weeks of therapy, fasting concentrations of blood glucose were below control levels in S.M. (Table V) and M.C. (Figure 2) and were falling toward control levels in B.D. (Figure 1). Fasting concentrations of blood pyruvate were increased (Figures 1, 2 and 3 ) while those of lactate were decreased (Figures 2 and 3 and Tables IV and V) in four patients so studied.

Decreased glucose tolerance was observed in the three patients with hypopituitarism. Data from M.C. are shown in Figure 3. In S.M., after 30 days of $\mathrm{HGH}$, glucose concentrations were: fasting, $62 ; 1$ hour past glucose, 171; and 2 hours after glucose, $198 \mathrm{mg}$ per $100 \mathrm{ml}$. In

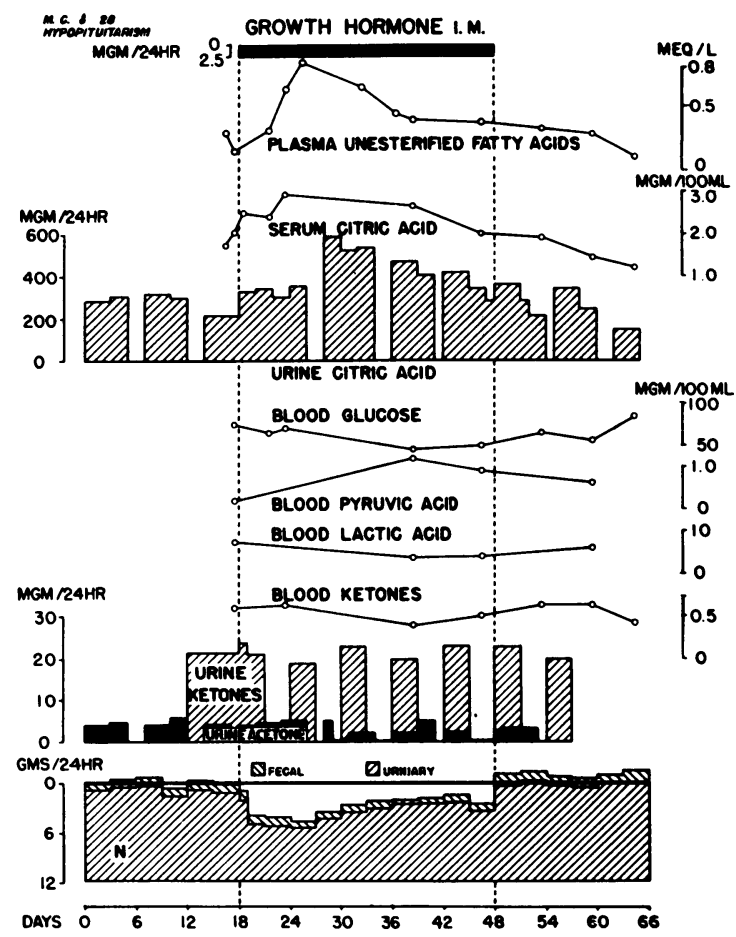

Fig. 2. EFfects of prolonged HGH administration in M.C. (hypopituitarism). No measurements of urinary citrate, acetone and ketones were made on the days when no values are shown. Urinary lactate and pyruvate were determined throughout the study and showed no significant change. Blood samples were taken as indicated in legend for Figure 1.

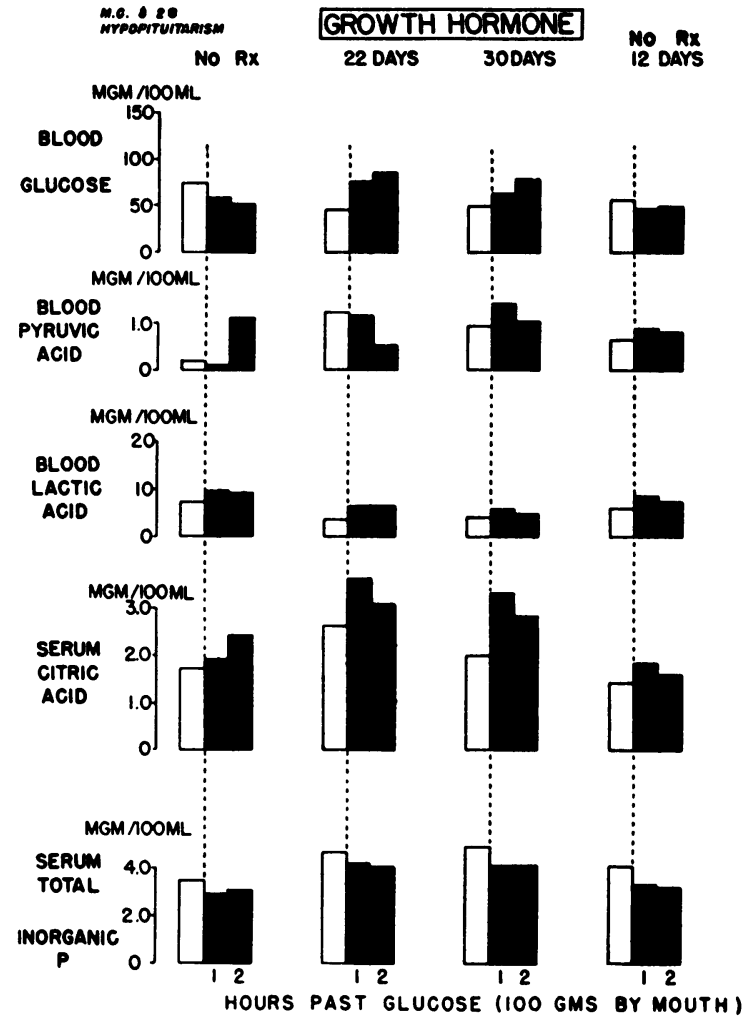

Fig. 3. EFFECTS OF HGH ON RESPONSE TO GLUCOSE IN M.C. (Hy POPITUitARISM). Glucose $(100 \mathrm{~g})$ was administered by mouth after a 15 hour fast. Blood samples were taken before, 1 and 2 hours after the ingestion of the glucose. Open blocks represent fasting samples; solid blocks represent postglucose samples.

M.A., after 30 days of $\mathrm{HGH}$, glucose concentrations were actually lower than those observed after 12 days of $\mathrm{HGH}$ : fasting, $68 ; 1$ hour after glucose, 100 ; and 2 hours past glucose, $86 \mathrm{mg}$ per $100 \mathrm{ml}$.

When HGH was discontinued in the patients with hypopituitarism, urinary citrate and ketones fell to or below control (Figure 2 and Table V).

\section{DISCUSSION}

Human growth hormone in man produces consistent changes in serum and urinary citrate and ketones, plasma free fatty acids and glucose tolerance. Elevations in plasma FFA and serum and urinary citrate generally preceded detectable changes in nitrogen metabolism. As suggested by studies in small animals (11) these changes may reflect primary fat mobilization which would increase the supply of two-carbon fragments for 
subsequent disposal via the tricarboxylic acid cycle and thereby provide energy and substrate for subsequent protein synthesis. It is of special interest that B.D., an obese patient who was mobilizing fat due to caloric restriction, demonstrated similar elevations in plasma FFA and serum and urinary citrate prior to HGH. The nitrogen balance data (1) suggest a one to three day delay in establishment of maximal nitrogen retention and a waning of such maximal retention after three weeks' continuous treatment. Changes in levels of blood and urinary metabolites showed similar time relations. Thus it appears that the early metabolic response to $\mathrm{HGH}$ may not be identical with the response to more prolonged administration of the hormone. The relation of these changes to rate and magnitude of changes in various pathways of cellular intermediary metabolism is uncertain at present.

\section{SUM MARY}

Administration of human growth hormone ( $\mathrm{Ra}$ ben) to five patients with hypopituitarism, one with hyperinsulinism, and one with obesity produced alterations in blood levels of carbohydrate and fat metabolites which preceded marked detectable changes in protein metabolism by approximately 24 hours. There was a prompt rise in plasma free fatty acids and blood and urinary citrate and ketones.

Continued daily doses of human growth hormone produced marked nitrogen retention, glucose intolerance, a sustained rise in plasma free fatty acids and serum and urinary citrate, elevations in blood pyruvate and a decrease in blood lactate. Administration of human growth hormone for more than two to three weeks resulted in gradual return of nitrogen excretion and blood and urinary metabolites toward control levels but continued glucose intolerance.

\section{REFERENCES}

1. Henneman, P. H., Forbes, A. P., Moldawer, M., Dempsey, E. F., and Carroll, E. L. Effects of human growth hormone in man. J. clin. Invest. 1960, 39, 1223.

2. Raben, M. S., and Hollenberg, C. H. Effect of growth hormone on plasma fatty acids. J. clin. Invest. 1959, 38, 484.

3. Beck, J. C., McGarry, E. E., Dyrenfurth, I., and Venning, E. H. The metabolic effects of human and monkey growth hormone in man. Ann. intern. Med. 1958, 49, 1090.

4. Ikkos, D., Luft, R., and Gemzell, C. A. The effect of human growth hormone in man. Acta endocr. (Kbh.) 1959, 32, 341.

5. Crigler, J. F., Jr., Knapp, J. A., and Chagnon, J. Observations on the metabolic effects of glucagon and growth hormone (human and beef) in an infant with idiopathic hypoglycemia and hyperinsulinism. J. Dis. Child. 1958, 96, 432.

6. Henneman, D. H., and Bunker, J. P. The pattern of intermediary carbohydrate metabolism in Cushing's syndrome. Amer. J. Med. 1957, 23, 34.

7. Davis, B. D. The estimation of small amounts of fatty acid in the presence of polyoxyethylene sorbitan partial fatty acid esters ("Tween") and of serum proteins. Arch. Biochem. 1947, 15, 351.

8. Gordon, R. S., Jr., and Cherkes, A. Unesterified fatty acid in human blood plasma. J. clin. Invest. 1956, 35, 206.

9. Reifenstein, E. C., Jr., Albright, F., and Wells, S. L. The accumulation, interpretation, and presentation of data pertaining to metabolic balances, notably those of calcium, phosphorus, and nitrogen. J. clin. Endocr. 1945, 5, 367.

10. Henneman, D. H., and Henneman, P. H. Depression of serum and urinary citric acid levels by 17-hydroxycorticosteroids. J. clin. Endocr. 1958, 18, 1093.

11. Greenbaum, A. L. Growth hormone and fat metabolism in The Hypophyseal Growth Hormone, Nature and Actions, R. W. Smith, Jr., O. H. Gaebler and C. N. H. Long, Eds. New York, Blakiston Division, McGraw-Hill, 1955, pp. 330343. 